\title{
The Role of China's Bureaucracy in its No-Devaluation Policy during the Asian Financial Crisis
}

\author{
LEONG H. LIEW \\ School of International Business and Asian Studies, Griffith University, \\ Nathan 4111, Australia \\ L.Liew@griffith.edu.au
}

\begin{abstract}
Analysts have generally offered two explanations for China's no-devaluation policy during the Asian financial crisis. The first is China's good economic fundamentals and the renminbi is not fully convertible. The second is China's foreign relations' imperative. China was endeavouring to seek favourable entry conditions into the WTO and improve relations with its Asian neighbours. At the same time it sought to exploit the undercurrent of resentment in Asia towards the role played by the US during the crisis. Policy making in China has become more institutionalized in the post-Deng era, but these explanations ignore the role of China's domestic bureaucratic actors in exchange rate policy making. This paper examines the exchange rate regime preferences of China's key economic ministries and their influences in exchange rate policy making and argues that Party leaders were able to adopt a no-devaluation policy throughout the crisis because China's key economic ministries actively supported or acquiesced to that policy.
\end{abstract}

\section{Introduction}

During the late 1990 os Asian financial crisis fears were expressed that China would devalue its currency, the renminbi (RMB), a move that would further destabilize the other economies of East Asia. Many Asia-Pacific leaders, including US President Clinton, praised China for not devaluing the RMB at this crucial time. In his speech to the World Economic Forum in Beijing, Singapore's Minister for Information, George Yeo, contrasted the Asian region's views of Japan and China. Had Japan exercized global leadership, according to Yeo, 'the Asian financial crisis would have been quickly

I wish to thank Elsie Leow for research assistance and the Australian Research Council for financing research that informs this paper. An earlier version of this paper was presented at a seminar at the East Asian Institute, National University of Singapore. I wish to acknowledge the comments from participants at this seminar, which have helped to improve the paper. 
stabilized'. Yeo claimed the 'determination of the Chinese government not to devalue the RMB, in order not to destabilize Asia further, will long be remembered' (Kelley, 1998). The then Thai Prime Minister, Chuan Leekpai, also publicly thanked China for maintaining the value of the RMB as well as its financial contribution to the IMFsponsored financial assistance package for Thailand. China's leaders took no time to talk up China's promise to maintain the value of the RMB. The cover story of the Chinese government's weekly international mouthpiece, Beijing Review, 9-15 March, 1998, was 'RMB won't devalue'. The same weekly in its coverage of the recently concluded Second Asian European Meeting (ASEM) reported on the compliments China received for its conduct in the Asian crisis from Dutch Prime Minister, Wim Kok and European Commission President, Jacques Santer (Feng, 1998).

Liew (1998: 322-323) pointed out the international relations imperative for China not to devalue its currency. China was negotiating entry into the WTO and was hoping that its promise of not devaluing the RMB would lubricate its entry into the WTO. In 1998, Chinese diplomats at the World Economic Forum in Davos went so far as to say that China was willing to risk a fall in its exports by maintaining the value of the RMB as part of its contribution to gain entry to the WTO. By not devaluing, China was also endeavouring to improve relations with its Asian neighbours and exploit the underlying feelings of resentment in Asia towards the US. Many governments in the region believed that the US was not doing enough to overcome the crisis, or worse, was exploiting the crisis to buy Asian assets on the cheap and gain easy access to Asian markets. China's leaders were also keenly aware that China's trade surplus with the US was a major irritant in Sino-US relations and devaluation of the RMB would have exacerbated the existing tensions between the two countries. The then US Secretary of State Madeline Albright, for example, warned that China should take steps to reduce its trade surplus with the US before this surplus became 'a source of estrangement instead of engagement' between the two countries (Beck, 1998).

Other scholars, among them Huang and Yang (1998: 5) and Song (1998) explained that the Chinese government had no reason to devalue. In their view, China's economic fundamentals were solid and with the RMB not fully convertible, there was little fear of massive capital flight from China. Naughton (1999: 208) and others believed that while China could not be forced to devalue because its currency is not fully convertible, it had reasons to devalue because it had lost its competitive position following devaluation of the currencies of its major Asian trading partners. In 1998 China's exports to these countries fell dramatically. Exports to ASEAN fell by 10.5 per cent, to Japan by 4.3 per cent and to South Korea by 30.2 per cent (HKTDC, 1998) and many economists in and outside China expressed fears that China's targeted growth rate of 8 per cent for 1998 might not be achieved. Hundreds of thousands of workers had been laid off from state-owned enterprises (SOEs) since 1993 as part of enterprise reform, and many loss-making SOEs owed workers millions of RMB in unpaid entitlements. Disaffected workers have set up numerous organizations that the government sees as illegal to organize resistance and protests against unemployment (Lai, 1999: 54). China's leaders continue to fear further 
social instability if unemployment increases. There was therefore immense domestic pressure on China's leaders during the Asian crisis to devalue.

Yet one area of this domestic pressure on devaluation policy that has largely escaped critical assessment is the bureaucracy. Policy making in China has become more institutionalized in the post-Deng era (Bachman, 2001; Shambaugh, 2001), but existing explanations on China's no-devaluation policy during the crisis ignore the role played China's domestic bureaucratic actors in determining that policy. There is therefore the need to examine the exchange rate regime preferences of China's key economic ministries and their influences in exchange rate policy making. This paper adopts a political economy approach to explore the institutional environment rules and bureaucratic self-interest - under which these key ministries operate and explains why the environment led to bureaucratic support for, or acquiescence to, no-devaluation during the crisis.

\section{China's bureaucracy and exchange rate policy}

The core of Deng Xiaoping's administrative reform in the 1980 os was to reform the state bureaucracy and redefine its relationship with the Party (Zheng, 1997: 212). The bureaucracy was professionalized with a greater stress on academic qualifications and a process was initiated to replace old revolutionary cadres with young technocrats. Although efforts to reduce the influence of the Party in state administration slowed after Zhao Ziyang was ousted as Party Secretary General in 1989, the administrative reforms of Deng that had given state institutions more legitimacy and authority were not reversed (Zheng, 1997: 264). More importantly, Deng's policies of domestic market reforms and increased participation in the global economy, which have reduced the power of the Party over the economy, have not been reversed but have been speeded up instead, especially after 1992. China's decentralized and more open economy requires greater coordination of economic policy making and implementation among economic ministries than was required under central planning. Moreover, in the post-Deng era there is no longer a supreme leader who can unilaterally impose policies and no single faction dominates the Party, compelling senior Party leaders to consult and compromise with one another (Huang, 2000: 426). All these developments have contributed to the greater institutionalization of economic policy making.

A useful way to explain exchange rate policy outcomes is to use Frieden's (1991) schema of exchange rate policy preferences of economic actors (Figure 1). Frieden sees sectors in the economy that are directly affected by exchange rate changes as the key actors influencing exchange rate policy. Traded (export and import-competing) sectors face international competition and therefore prefer a low exchange rate (price of domestic currency relative to price of foreign currency) that makes them more competitive at home and in foreign markets against foreign goods. On the other hand, non-traded sectors produce goods and services that are not sold abroad and face no foreign competition at home. These sectors therefore prefer a high exchange rate. Import-competing and non-traded sectors depend heavily on domestic sales and 
Preferred degree of exchange rate flexibility

\begin{tabular}{|c|c|c|c|}
\hline & & High & Low \\
\hline \multirow{2}{*}{$\begin{array}{l}\text { Preferred level of } \\
\text { exchange rate }\end{array}$} & High & $\begin{array}{l}\text { Producers of non-traded } \\
\text { goods and services }\end{array}$ & $\begin{array}{c}\text { International traders } \\
\text { and investors }\end{array}$ \\
\hline & Low & $\begin{array}{l}\text { Import-competing producers } \\
\text { of traded goods for the } \\
\text { domestic market }\end{array}$ & $\begin{array}{l}\text { Export-oriented } \\
\text { producers of } \\
\text { traded goods }\end{array}$ \\
\hline
\end{tabular}

Source: Frieden (1991): 445.

Figure 1 Exchange rate policy preferences of economic actors

therefore prefer national monetary policy autonomy, which enables domestic demand to be adjusted as required. National monetary policy autonomy, however, requires exchange rate flexibility. This reasoning follows from the Mundell-Fleming proposition, that in the presence of international capital mobility the degree of effectiveness of monetary policy depends on the degree of flexiblity in the exchange rate. This is because the freedom that the national monetary authority has to vary domestic interest rates depends on the flexibility of the exchange rate. In a fixed exchange rate regime the hands of the monetary authority are tied (Fleming, 1962; Mundell, 1963). Exporters and international traders and investors depend more on foreign than domestic markets and they experience exchange rate risk in the presence of exchange rate fluctuations. These actors therefore prefer a low degree of exchange rate flexibility.

According to Frieden, exchange policy outcomes can be understood by analysing the relative strengths of sectoral winners and losers of exchange rate policy in the domestic polity. Frieden's schema is simple but it provides insights into how exchange rate polices of liberal industrialized market economies are determined. However, his approach is less useful when it comes to explaining exchange rate policies in a country like China that does not have a well-developed civil society. In liberal industrialized market economies, individual businesses, business and trade associations, professional associations and learned societies often openly agitate for particular economic policies. This phenomenon is absent in China. Chinese civil society is still very weak despite more than two decades of economic reform. The author and a research assistant spent several weeks going over several major Chinese national and sub-national newspapers published in 1998 and the first half of 1999. The papers include the Jingji Ribao (Economic Daily), Shanghai Jingji Bao (Shanghai Economic Daily), Shenzhen Shang Bao (Shenzhen Commercial Daily) and Xiamen Ribao (Xiamen Daily). The last three 
papers are published in localities that are highly dependent on exports and where one would expect to find significant opposition to the government's no-devaluation policy during the Asian financial crisis. However, we did not find a single article questioning the government's no-devaluation policy. Although we covered only a small proportion of the newspapers that are published in China, our findings here of an absence of a strong independent media are consistent with findings of other scholars working on China's civil society (for example, Baum and Shevchenko, 1999 and He, 1997: 147-177) that indicate the presence of a developing but still weak civil society. With a weak civil society, contestations over exchange rate policy in China are therefore played out largely out of sight, within the bureaucracy.

In China, a small joint party-state committee comprising top party and state leaders - the Central Leading Group in Finance and Economics (CLGFE) - makes key economic policy decisions. During the Asian financial crisis the CLGFE nominally headed by Party General-Secretary Jiang Zemin but directed by Premier Zhu Rongji decided exchange rate policy, with policy inputs from key economic ministries. Contestation over exchange rate policy took place largely among these ministries, with limited participation from China's small emerging civil society. The four most influential economic ministries with an interest in exchange rate policy in China are the State Development and Planning Commission (SDPC), Ministry of Foreign Trade and Economic Cooperation (MOFTEC), Ministry of Finance (MOF) and People's Bank of China (PBC), which has ministerial status. Their functions within the structure of economic policy determine the views that each hold on exchange rate policy and how influential these four ministries are in the making of exchange rate policy. In hierarchical terms, a commission ranks above a ministry, but for the purpose of this paper commissions and ministries are collectively referred to as ministries. The following sub-sections will explain the exchange rate regime preferences of these four key economic ministries and their exchange rate policy preferences during the Asian crisis. Figure 2 shows the schema of exchange rate policy preferences of these ministries.

\section{State Development Planning Commission (SDPC)}

Under central planning, the State Planning Commission (SPC), the forerunner of SDPC, was the most influential economic ministry. It was responsible for drawing up the national economic central plan and for its implementation. The market was highly circumscribed under Mao and was given only a very limited role in the early years of post-Mao economic reform. The prevailing orthodoxy then was that the plan should allocate most resources, recognizing central planning and state ownership as sine qua non of a socialist economy. The SPC set prices, determined production quotas that firms had to meet and allocated materials and other goods to intermediate and end users. But since 1992, the Party implemented the policy of transforming China into a 'socialist market economy' (shehui shichang jingji), largely replacing the plan with the market as the preferred mechanism for distribution. Prices, production and 
Preferred degree of long-term exchange rate flexibility

\begin{tabular}{|l|l|c|c|}
\cline { 3 - 4 } \multicolumn{1}{c|}{} & \multicolumn{1}{c|}{ Moderate } & Fixed \\
\cline { 2 - 4 } \multicolumn{1}{c|}{$\begin{array}{c}\text { Preferred } \\
\text { short-term } \\
\text { exchange rate } \\
\text { direction }\end{array}$} & No devaluation & PBC & SDPC, MOF \\
\cline { 2 - 4 } & Devaluation & & MOFTEC \\
\hline
\end{tabular}

Figure 2 Exchange rate policy preferences of China's key economic ministries during the Asian financial crisis

sales are left largely to the market and central planning and state ownership are no longer sine qua non of a socialist economy. The administrative tools of central planning from the Mao period are no longer relevant for managing the economy. Instead, the indirect economic levers of monetary and fiscal policies are now the standard tools of macroeconomic management. These tools, however, are under the responsibility of $\mathrm{PBC}$ and MOF, which in the days of central planning had much lower status than SPC. The PBC was under the MOF, which basically followed the lead of SPC. As a result of the market replacing the plan, the status of $\mathrm{PBC}$ and MOF was increased at the expense of SPC and its descendant, SDPC. SDPC now limits itself to long-term planning, drawing up and implementing investment plans only for major national development projects. Administrative decentralization has also meant that sub-national governments are responsible for more state investments, which do not fall under the control of SDPC. The reduction in SDPC's influence is evidenced by the fact that in 1997 the central government's expenditure was only 3.4 per cent of GDP compared to 14.8 per cent in 1978 (GTJ, 2000: 65, 268). Nevertheless, because of its former status under central planning as the most important and influential economic ministry and because state investment in China is still substantial, SDPC's influence on the economy is still considerable.

SDPC benefits from and therefore supports policies that increase state investment in infrastructure and argues against policies that increase costs of the infrastructure projects that it manages. Under central planning MOF provided whatever financial resources were required by SPC to implement the economic plan that SPC had drawn up. But this changed with fiscal decentralization, which has reduced the growth in tax revenues and limited the capacity of the state to provide public goods. Budgetary revenues fell from 35 per cent of GDP in 1978 to only 11.6 per cent in 1997 (GTJ, 2000: 246). Now, although SDPC remains highly influential, it has to compete for resources with other areas in the bureaucracy. 
Domestic devaluation, monetary expansion and fiscal stimulus are alternate means of stimulating a domestic economy. SDPC does not favour devaluation and is often lukewarm on monetary expansion because devaluation and monetary expansion tend to increase domestic prices, reducing the amount of real resources that SDPC can spend on infrastructure projects. In addition, SDPC is concerned with exchange rate fluctuations, which introduce uncertainty to large project management that involves significant foreign inputs. China's finance industry is still relatively undeveloped with limited opportunities for hedging foreign exchange risks and this makes SDPC prefer exchange rate stability. During the Asian crisis, the Chinese economy was suffering from deflation so the inflationary consequences of devaluation were not a prime concern of SDPC. But fiscal stimulus in the form of increased state investment in infrastructure provides additional resources to SDPC and increases its influence. The SDPC therefore prefers fiscal stimulus to devaluation as a means to stimulate China's economy. The SDPC and the PBC were the economic ministries most supportive of China's nodevaluation and fiscal stimulus policies during the Asian financial crisis.

\section{People's Bank of China (PBC)}

The PBC was established in 1948, but China's State Council established it as a central bank and granted it ministry status only in September 1983 (Dai, 1998). Before September 1983 PBC had no influence over the RMB exchange rate and its influence over economic policy was limited. SPC specified the amount of goods to be produced, total demand in the economy, level of savings and prices. The role of $\mathrm{PBC}$ was to respond to the plan by providing the necessary money supply in the cash and credit plans to ensure that the targets in the production and expenditure plans could be implemented. Thus, PBC helped to ensure that the economic plans laid down by SPC were adhered to through its supervision and monitoring of the flow of funds in the economy. The PBC's low status in the economic planning hierarchy was such that between 1969 and 1976, during the Cultural Revolution, the PBC lost its independent identity and was absorbed within the MOF to serve purely as a bookkeeper of financial and planning accounts (ZRYY, 1999: 6).

Money and finance drive modern market economies. The Asian financial crisis has demonstrated the importance of proper regulation and governance in the banking sector. It is therefore not surprising that $\mathrm{PBC}$ has become more and more influential as the Chinese economy becomes progressively marketized. The rise in central banks' influence on national economies as a result of globalization is observed around the world. In 1983, the Reserve Bank of Australia (RBA) and the Australian Treasury differed over whether the Australian dollar should be floated. The former was in favour and the latter was against. Outwardly, Treasury claimed to be against floating the dollar because it feared this would be inflationary. But the real reason according to John Edwards, senior economic adviser to then Treasurer Paul Keating, was that the float would make the RBA independent of Treasury and turn Treasury into a junior partner of the RBA 
in short-term macroeconomic policy formulation (Edwards, 1996: 216, 230). This is because the floating of the $\$ A$ and removal of exchange controls that accompanied the float would, according to the Mundell-Fleming proposition, make monetary policy more effective than fiscal policy in determining the level of economic activity.

In 1995 China's parliament, the National People's Congress (NPC), legally enshrined the PBC's position as the country's central bank by passing the PBC Act. The Act's passage made the PBC responsible for regulating the country's financial system and for short-term macroeconomic management, including maintaining the stability of the value of the RMB and prices. The exchange rate was made formally an instrument for the conduct of monetary policy and not an instrument to promote international trade, which increased the influence of the $\mathrm{PBC}$ over exchange rate policy at the expense of MOFTEC. On 1 December 1996, the State Council announced that the RMB had been made convertible in the current account and from 1998 PBC began to pay attention to the link between interest rate and exchange rate, taking note of the influence of foreign exchange on the volume of base money (ZRYY, 1999: 11).

China experienced two serious bouts of inflation in the reform period. The first was in the late 1980 s when price reform and a lose monetary policy set off an inflationary spiral that was exploited by corrupt officials illegally selling goods in the plan to the market, which contributed to the massive demonstrations against the Party in Beijing in 1989. The second was during 1992-1994, after Deng Xiaoping's southern tour to push through more economic reform set off a speculative boom that required strong action by Zhu Rongji, who was governor of $\mathrm{PBC}$ at that time, to bring it under control. As part of a conscious effort to control inflation, the RMB/\$US rate was fixed as an anchor to stabilize China's inflation rate (He, 2000: 19). In 1998, despite facing a deflationary economy, $\mathrm{PBC}$ was still concerned with the inflationary effects of a loose monetary policy and RMB devaluation. PBC was so concerned with inflation that real interest rates at the end of 1998 were still around 8 per cent. Deflation kept real interest rates high despite nominal monetary expansion. This may be surprising but central banks, especially those in industrialized countries, have such strong preferences against inflation that they are often reluctant to adopt any policy that is remotely inflationary. German and Japanese central banks are prime examples of central banks exhibiting this behaviour, which have caught the attention of economists. The economist Paul Krugman, for example, has been a constant critic of the Bank of Japan for its unwillingness to raise inflationary expectations to get Japan off its deflationary spiral even though the Japanese economy has been in prolonged recession since the bursting of Japan's so-called 'bubble economy' in the early 1990s (Krugman, 1998). The PBC's strong anti-inflationary position simply mirrors a similar position that is common among its counterparts in the West.

In July 1997 Hong Kong reverted to Chinese sovereignty. Under the Basic Law, Hong Kong is to manage its own affairs for 50 years after the reversion. This means that the Hong Kong Monetary Authority (HKMA) continues to be responsible for maintaining the stability of the financial system of Hong Kong. Chinese leaders recognize that 
they cannot be seen to be acting in ways that adversely affect Hong Kong's economy and $\mathrm{PBC}$ 's international department has among its many responsibilities, liasing with HKMA to preserve the stability of Hong Kong's financial system and economy. During the financial crisis many financial analysts expressed concern that devaluation of the $\mathrm{RMB}$ would make it difficult for the Hong Kong Monetary Authority (HKMA) to preserve the \$HK/\$US peg, which was necessary for maintaining investors' confidence in the Hong Kong economy (Li Fuyang, 1998: 6-7; Zhao, 1998: 29-31). In one survey of currency traders in Hong Kong, 51 per cent of them believed that devaluation of the RMB would have led to devaluation of the $\$ \mathrm{HK}$ and 70 per cent believed that devaluation of the $\$ H K$ would have ended Hong Kong's currency board arrangement (Liew and Wu, 2002: 452). In 1993, the then deputy governor of PBC, Chen Yuan, made a pledge in Hong Kong that the PBC will cooperate with HKMA to maintain both the financial stability of Hong Kong and Hong Kong's position as a major international financial centre (Chen, 1993/94). Given its concern for stability of the $\$ \mathrm{HK}$ and desire to use the RMB/\$US peg as an anchor to control inflation at the time of the financial crisis, $\mathrm{PBC}$ preferred no-devaluation and exchange rate stability.

The $\mathrm{PBC}$ recognizes that the $\mathrm{RMB} / \$$ US peg reduces the effectiveness of monetary policy in the presence of international capital mobility. Despite stringent capital controls, between 1992 and 1996, China's informal capital outflow was 43 per cent of formal capital inflow (Li Yang, 1998, cited in Huang and Yang, 1998: 5). Capital controls are to be relaxed further after China joins the WTO. Thus, while PBC may continue to favour maintaining the $\mathrm{RMB} / \$ \mathrm{US}$ peg in the future, it favours progressively enlarging the band within which the RMB/\$US rate is allowed to divert from the fixed $\mathrm{RMB} /$ US peg. Dai Xianglong, PBC's governor, said this at an interview with the US business magazine, Business Week (Policy, 2001) and his reason is no doubt to increase the effectiveness of monetary policy as capital controls are relaxed, lest PBC loses out to MOF in influence over macroeconomic policy making.

\section{Ministry of Finance (MOF)}

Under central planning, MOF was in the shadow of SPC and did not enjoy the same status as its counterparts in industrialized countries. Its status has been raised since the 1980 os because economic reform and fiscal decentralization have meant that the central government has less control over enterprises and households and has to rely on indirect economic levers such as fiscal and monetary policies, rather than administrative orders, to direct the economy. This means a transfer of substantial responsibility and power from SDPC to both MOF and PBC. The MOF (together with the PBC) is responsible for managing China's short-term macroeconomy, to maintain high levels of annual economic growth while keeping inflation under control. It must also ensure that its fiscal policies raise sufficient central budgetary revenues to finance central government expenditures. These responsibilities of the MOF determine its views on exchange rate policy. 
Table 1. Contribution to China's GDP growth (percentages)

\begin{tabular}{lllllrl} 
& HC & GC & GFCF & INV & Net X & GDP growth \\
\hline 1992 & 6.6 & 2.0 & 7.3 & -0.8 & -1.1 & 14.1 \\
1993 & 4.9 & 1.5 & 7.1 & 1.1 & -1.5 & 13.1 \\
1994 & 5.3 & 1.5 & 4.0 & 0.4 & 1.4 & 12.6 \\
1995 & 4.7 & 0.5 & 2.6 & 0.9 & 0.3 & 9.0 \\
1996 & 5.1 & 1.1 & 3.0 & 0.0 & 0.5 & 9.7 \\
1997 & 3.5 & 1.1 & 2.4 & -0.3 & 1.8 & 8.6 \\
1998 & 3.9 & 1.4 & 4.7 & -2.6 & 0.4 & 7.8 \\
1999 & 5.1 & 1.7 & 3.8 & -1.9 & -1.7 & 7.1 \\
\hline
\end{tabular}

Note: $\mathrm{HC}=$ household consumption, $\mathrm{GC}=$ government consumption, GFCF $=$ gross fixed capital formation, INV = change in inventories, NET X = net exports. Addition across each row gives GDP growth.

Source: Estimated from data in GTJ (2000) by the author. GFCF is likely to be overestimated and INV underestimated because capital goods ordered from state-owned enterprises (SOEs) by state sector units, including other SOEs, but not delivered are normally recorded as GFCF rather than INV.

In the course of 1998, the decline in regional incomes in Asia and falls in the yen and other Asian currencies worsened China's foreign trade position, contributing to a slow down of China's economic growth. Estimates of the contribution to GDP growth from different expenditure components of GDP for 1992-1999 are shown in Table 1. The estimates clearly show a significant decline in the contribution of net exports to GDP growth in 1998 that was exacerbated by falls in household consumption. By the middle of 1998 the Chinese leadership was becoming desperate. It was concerned that a growth rate lower than 8 per cent would be insufficient to absorb rising unemployment from enterprise reform to prevent political and social instability. Preliminary Figures in 1998 showed that annual economic growth in the first half of 1998 was only 6.6 per cent, well short of the targeted 8 per cent (Luo, 1998: 6-7). In 1999, China's foreign trade position worsened. The contribution of net exports to GDP growth became negative for the first time since 1993 .

The contribution of net exports to GDP in 1997 was unusually high and net exports could not be expected to continue to grow at the 1997 rate in 1998 and 1999. Nevertheless, the negative contribution of net exports to GDP growth in 1999 indicated a serious decline in China's external sector. China clearly had to rely on domestic demand to achieve its growth targets for 1998 and 1999. Massive increases in state capital spending and measures such as more public holidays and higher welfare payments to stimulate household consumption were used to stimulate domestic demand. State budgetary appropriations to capital construction increased from RMB 57.5 billion in 1997 to RMB102.1 billion in 1998 and RMB147.9 billion in 1999 (GTJ, 2000: 174). In 1998, capital investment was responsible for 4.7 per cent of the 7.8 per cent growth rate, a share of 60.3 per cent. A year later, its contribution was 3.8 per cent of 7.1 per cent, a share of 53.5 per cent. 
Monetary policy was relatively ineffective during the Asian crisis and responsibility for stimulating domestic demand was placed largely on the shoulders of fiscal policy. Non-government investment remained sluggish even though the PBC lowered interest rates five times in 1998 because the crisis had lowered business confidence. Businesses were apprehensive about new projects while commercial banks became more cautious of bad loans and were reluctant to lend (Zhang, 1999: 181). Furthermore increased marketization resulting from economic reform has increased competition in China's economy. This combined with the low level of business confidence in 1998 created deflationary pressures. Consumer prices fell by 0.8 per cent and retail prices by 2.6 per cent in 1998 compared to a year earlier. In 1999 consumer prices fell a further 1.4 per cent and retail prices by 3 per cent (GTJ, 2000: 289) and many enterprises and consumers postponed their spending in anticipation of a further fall in prices. Although PBC lowered interest rates, deflation acted to keep real interest rates high, providing additional disincentives to private sector spending.

The MOF like finance ministries everywhere is a fiscal conservative that does not normally favour fiscal deficits to stimulate the economy. Neither does it favour reimbursing exporters for the mandatory VAT, recognizing that it is not possible to reimburse exporters for the whole 17 per cent of VAT to encourage exports without severely affecting central finances. From 1995 the MOF reimbursed exporters 9 per cent of VAT, leaving an effective tax on exports of 8 per cent (Long, 1999: 412). The Development Research Centre of the State Council had estimated that every 1 per cent increase in the VAT reimbursement rate increased GDP by 0.6 per cent and increased tax revenues by 0.9 per cent. However, the increase in tax revenues would flow mainly to provincial governments and not to the central government because of the way in which revenues from different taxes are distributed between provincial and central governments (Long, 1999: 413-414). But this was not a big issue for the MOF in 1998. Central finances had gradually improved since the tax reform of 1994. They were not as bleak as in 1989, when the centre received only 31 per cent of total budgetary revenue (Long, 1999: 267). Budgetary revenue as a percentage of GDP had increased from 10.9 per cent in 1996 to 11.6 per cent in 1997 and to 12.6 per cent in 1998 (Long, 1999: 256). During the same period, the central government was able to increase its share of total budgetary revenue, raising it from 48.9 per cent in 1997 to 49.5 per cent in 1998 and 51.1 per cent in 1999 (Long, 1999: 267). Budget deficit was 0.8 per cent of GDP in 1996 and 1997 and even after the substantial government spending increases of 1998 it was still a modest 1.2 per cent of GDP. The deficit increased to 2.2 per cent in 1999 (Long, 1999: 53, 255), but by 2000 economic recovery in the rest of Asia had removed the pressure for China to devalue.

The MOF is not necessarily against government spending because its influence depends on the size of government expenditure as well as taxation. What it is against is deficit financing. Hence, the MOF was not against relying on increases in government spending rather than devaluation to boost the growth rate in 1998. This was made clear in a book published by several senior researchers from the SDPC, the MOF and other 
government ministries, where they expressed strong support for increased government expenditures (Bai et al., 1998). Moreover, the influence of the MOF is enhanced by a stable exchange rate. The influence of the MOF to some extent depends on its role in implementing fiscal policy for macro management of the economy. As a competitor with $\mathrm{PBC}$ for policy influence, the MOF favours continuation of the RMB/\$US peg. This is because capital mobility is expected to increase significantly in response to relaxation of capital controls now that China has joined the WTO, making fiscal policy more effective than monetary policy with a stable exchange rate.

\section{Ministry of Foreign Trade and Economic Cooperation (MOFTEC)}

When the Chinese authorities commenced economic reform in 1978, foreign investment in China was virtually non-existent and foreign trade only 9.8 per cent of GDP (GTJ, 2000: 65, 587-588). Today, foreign trade and investment are highly important for China. In 1998 foreign trade was 34 per cent of China's GDP and foreign investment, 5.3 per cent of GDP. The importance of foreign trade and investment in the reform period has increased the influence of MOFTEC in exchange rate policy, which reached its peak in 1994 .

The liberalization of foreign trade was conducted pari passu with liberalization of the domestic economy in the 1990 s and exporters and importers began to respond to market price (Cerra and Dayal-Gulati, 1999: 13-15). MOFTEC therefore has a vested interest in a low $\mathrm{RMB}$ exchange rate since this helps exports to be price competitive. As exporters still find it difficult to hedge against foreign exchange risk because financial markets are still underdeveloped in China, MOFTEC favours a stable exchange rate. However MOFTEC's influence over policy on the value of the RMB waned after 1994. As well as converting the exchange rate from an instrument to promote foreign trade to one for managing the macro economy the authorities in 1994 unified the official and the swap-market exchange rates with a devaluation of the official rate to bring it into line with the swap-market rate. Before 1994 China's exports were valued at the higher official exchange rate, which depressed prices for exporters. The 1994 devaluation raised prices for exporters and raised the profitability of foreign trade corporations. In the same year, a tax reform introduced tax rebates to compensate exporters for the 17 per cent VAT. As a result of the foreign exchange and tax reforms, MOFTEC's advocacy for a lower RMB carried less weight after 1994. During the Asian crisis pressure on MOFTEC to seek a lower exchange rate was eased further with relaxation of export controls and loans to export enterprises experiencing difficulty. Export quotas were abolished on 26 products and the number of products subject to export licenses was reduced from 115 in 1998 to 59 in 1999. In 1998, 15 per cent of the textile quota for export to the United States, which used to be totally controlled by the government, was allocated directly to exporting enterprises (Hai and Zhong, 1999).

As well as losing influence over exchange rate policy to PBC, MOFTEC has also become less aggressive in its pursuit of polices that favour the foreign trade sector. State enterprise reform has disengaged the enterprise from state administration, making 
MOFTEC no longer responsible for the profitability of trading corporations. MOFTEC can therefore afford to adopt a broader approach to exchange rate policy without keeping a narrow focus on the impact of exchange rate policy on the foreign trade sector.

\section{Conclusion}

Uncovering the institutional factors that influenced the views of China's key economic ministries on exchange rate policy allows one to understand why China's leaders were able to muster the support of key domestic institutions that was essential for them to maintain the value of the RMB during the Asian financial crisis, despite the enormous pressure on them to devalue. China's international relations imperative was a major factor behind its leaders' decision not to devalue but the ability of its leaders to hold to that decision was helped enormously by the key economic ministries' support or at least acquiescence to the leaders' policy stance.

The exchange rate policy preferences of China's key economic ministries during the Asian financial crisis are shown in Figure 2. Despite facing a deflationary economy, PBC was worried about inflation, a proclivity that seems to be common among major central banks around the world, including the German Bundesbank and the Bank of Japan. The PBC's concerns with inflation and stability of the \$HK led it to prefer a nodevaluation policy and continuation of the RMB/\$US peg. Nevertheless since a more flexible exchange rate makes monetary policy more effective relative to fiscal policy with capital liberalization, which is foreshadowed by China's entry into the WTO, PBC supports progressively widening the band within which the exchange rate is allowed to vary around the fixed $\mathrm{RMB} / \$$ US peg.

SDPC like PBC does not normally favour currency devaluation because it raises prices and therefore costs of major state infrastructure projects for which it is responsible. It also favours a stable exchange rate because of current limited hedging opportunities against foreign exchange risk, which can have an adverse impact on infrastructure project costs because of their high foreign input content. Inflation was not an SDPC concern in 1998 but SDPC nevertheless supported the no-devaluation policy because the additional demands placed on fiscal policy as a result of no devaluation would increase state investments in infrastructure projects and increase its influence. The MOF is a fiscal conservative and would have preferred devaluation to fiscal stimulus to stimulate the economy. However it acquiesced to a large fiscal stimulus and did not advocate strongly for devaluation. Tax revenues had increased and the MOF was aware that China's foreign trade sector in 1998 could not have repeated its excellent performance of the preceding year and therefore fiscal policy had to shoulder the major burden of achieving the 1998 GDP growth target of 8 per cent. The MOF prefers a stable exchange rate because as capital flows are liberalized, a stable exchange rate increases the relative effectiveness of fiscal policy relative to monetary policy and will likely strengthen its influence at the expense of PBC. 
MOFTEC was the ministry keenest on devaluation during the Asian crisis but its call for devaluation was muted by various measures including increased VAT reimbursements and financial assistance to exporters. MOFTEC has the same preference as SDPC in favouring a stable exchange rate because of limited hedging opportunities for exporters, a core constituent of MOFTEC. China's export-oriented coastal provinces, a core constituent of MOFTEC that can exert independent influence on exchange rate policy, were keen on devaluation. Their governments were a strong voice pushing for devaluation in the summer of 1998. Until then China's leaders had underestimated the severity of the crisis. As Table 1 shows, the foreign sector made a significant contribution to GDP growth in 1997 and the severe downturn in exports was only apparent from the beginning of the second quarter of 1998. The exchange rate quickly became a major policy issue and China's sub-national governments of export-oriented provinces put pressure on China's leadership to devalue at the Central Work Conference in Beidaihe in the summer of 1998. China's leadership was able to overcome this pressure from the provinces with other forms of assistance as compensation, of which at least one is preferred by the sub-national governments to devaluation. Governments of exportoriented provinces preferred higher VAT reimbursements because as mentioned earlier these yielded provinces more revenue than currency devaluation.

Many analysts that sought to explain China's no-devaluation exchange rate policy during the crisis looked for answers in China's economic fundamentals. While these analysts were able to explain why China could not be forced to devalue, they were unable to explain why China did not devalue despite having good economic reasons to do so. Other analysts highlighted China's international relations imperative not to devalue but their explanation is incomplete because it ignores the role of key economic ministries whose influence in exchange rate policy making is undeniable. The analysis in this paper complements earlier research on China's exchange rate policy during the Asian crisis by focusing on the role and relative influence of key economic ministries in exchange rate policy making. This paper argues that with the two most influential economic ministries - SDPC and PBC - supporting no-devaluation and the MOF adopting a no-devaluation to neutral position, MOFTEC, the least influential of the four ministries, had little chance to win the contest for its preferred policy of devaluation within the bureaucracy. With such support from within the economic policy pillars in the bureaucracy it is no wonder that President Jiang and Premier Zhu easily maintained the no-devaluation policy during the Asian financial crisis despite coming under heavy domestic pressure to devalue.

\section{References}

Bai Hejin et al. (1998), Jingji Zhongguo [Economics Oriented China], Beijing: Caizheng jingji chubanshe. Baum, R. and A. Shevchenko (1999), 'The "state of the state"', in M. Goldman and R. MacFarquhar (eds.), The Paradox of China's Post-Mao Reforms, Cambridge: Harvard University Press, pp. 333-36o.

Bachman, D. (2001), 'The Paradox of Analysing Elite Politics under Jiang', The China Journal, 45(January): 95-100. 
Beck, Simon (1998), 'Tang Gives Full Backing to Clinton', South China Morning Post, 3o September, http://www.scmp.com.

Cerra, V. and A. Dayal-Gulati (1999), 'China's Trade Flows: Changing Price Sensitivities and the Reform Process', Working Paper of the IMF, WP/99/1.

Chen Yuan (1993/94), 'Central Banking Reform in China', Central Banking, 4(3): 64-65.

Dai Xianglong (1998), Zhongguo Renmin Yinhang Wushinian [50 Years of the People's Bank of China], Beijing: Zhongguo jinrong chubanshe.

Edwards, J. (1996), Keating: The Inside Story, Ringwood: Penguin Australia.

Feng Zhongping (1998), 'ASEM II Attracts World Attention', Beijing Review, 41(11-17 May): 7-9.

Fleming, J. (1962), 'Domestic Financial Policies under Fixed and under Floating Exchange Rates', IMF Staff Papers, 9 (November): 369-379.

Frieden, J.A. (1991), 'Invested Interests: The Politics of National Economic Policies in a World of Global Finance', International Organisation, 45(4): 425-451.

Guojia Tongji Ju (GTJ) (200o), Zhongguo tongji nianjian [China Statistical Yearbook], Beijing: Zhongguo tongji chubanshe.

Hai Wen and Zhong Kaifeng (1999), 'The Impacts of the Asian Economic Crisis on China's Foreign Trade', unpublished manuscript, China Centre for Economic Research, Peking University.

He Baogang (1997), The Democratic Implications of Civil Society in China, New York: St. Martin's Press Inc.

He Liping (2000), 'The Future of the Exchange Rate Regime in China', World Economy and China, 8(3): $6-25$.

Hong Kong Trade Development Council (HKTDC)(1998), Market Profile on Mainland China, 9 October.

Huang, Jing (2000), Factionalism in Chinese Communist Politics, Cambridge: Cambridge University Press.

Huang Yiping and Yang Yongzheng (1998), 'China’s Financial Fragility and Policy Responses', Asian-Pacific Economic Literature, 12(2): 1-9.

Kelley, P. (1998), 'Great stumble forward', The Weekend Australian, 25-26 April, p. 28.

Krugman, P. (1998), 'Japan: still trapped', http://www.wws.princeton.edu/ pkrugman/ japtrap2.html.

Lai Rongwen (1999), 'Zhongguo dalu xiagang wenti zhi yanjiu' [Research on mainland China’s unemployment problem], Gongdang Wenti Yanjiu [Communist Party Research], 25(July): 54-66.

Li Fuyang (1998), 'Renminbi huilu de zhengce mubiao yu qushi fenxi' [Analysis of RMB Exchange Rate Trends and Objective of RMB Exchange Rate Policy], Zhongguo jinrong [China's Finance], 4: 6-7 and 17.

Li Yang (1998), 'Capital Flows of the Chinese Economy in the Process of Opening Up', Economic Research, 2 (February): 14-24.

Liew, Leong H. (1998), 'A Political Economy Analysis of the Asian Financial Crisis', Journal of the Asia Pacific Economy, 3(3): 301-330.

Liew, Leong H. and Harry X. Wu (2002), 'Not all Currency Traders Believe in Unfettered Free Markets: Currency Speculation and Market Intervention in Hong Kong', The China Quarterly, 170 (June): 441458.

Long Guoqiang (1999), 'Tiaozheng chukou tuishui zhengce de xiaoying fengxi' [Analysis of The Effect of Adjusting the Tax Reimbursement Policy on Exports], in Ma Hong and Wang Mengkui (eds.), Zhongguo Fazhan Yanjiu [China Development Studies Research], Beijing: Zhongguo fazhan chubanshe, pp. 409415.

Luo Bing (1998), 'Zhu Rongji lin jingji shenyuan' [Zhu Rongji's temporary economic abyss], Cheng Ming, 8(August): 6-7.

Mundell, R. (1963), 'Capital Mobility and Stabilisation Policy under Fixed and Flexible Exchange Rates', Canadian Journal of Economics and Political Science, 29(4): 475-485.

Naughton, B. (1999), 'China: Domestic Restructuring and a New Role in Asia', in T. J. Pempel (ed.), The Politics of the Asian Economic Crisis, Ithaca: Cornell University Press.

Shambaugh, David (2001), 'The Dynamics of Elite Politics during the Jiang Era', The China Journal, 45 (January): 101-111.

Policy, Peggy (2001), 'Beijing to Loosen Exchange Rate', South China Morning Post, 30 March.

Song Ligang (1998), 'China', in R. McLeod and R. Garnaut (eds.), East Asia in Crisis: From Being a Miracle to Needing One, London: Routledge, pp. 105-119.

The World Bank (1997), China 2020, Washington, DC: The World Bank. 
Zhang Chenghui (1999), 'Dangqian huobi zhengce de zuzhi yu tiaozheng' [Obstacles to current monetary policy and adjustment], in Ma Hong and Wang Mengkui (eds.), Zhongguo Fazhan Yanjiu [China Development Studies Research], Beijing: Zhongguo fazhan chubanshe.

Zhao Lingbin (1998), 'Renminbi shengbian dui Gangyuan huilu de yingxiang' [Effect of revaluation or devaluation of the renminbi on the \$HK exchange rate], Ming Pao (July): 29-33.

Zheng Shiping (1997), Party vs. State in Post-1949 China: The Institutional Dilemma, Cambridge: Cambridge University Press.

Zhongguo renmin yinhang yanjiuju (ZRYY)(1999), Zhongguo Xiandai Zhongyang Yinhang Tizhi[China's Contemporary Central Bank System], Beijing: Zhongguo jinrong chubanshe. 